
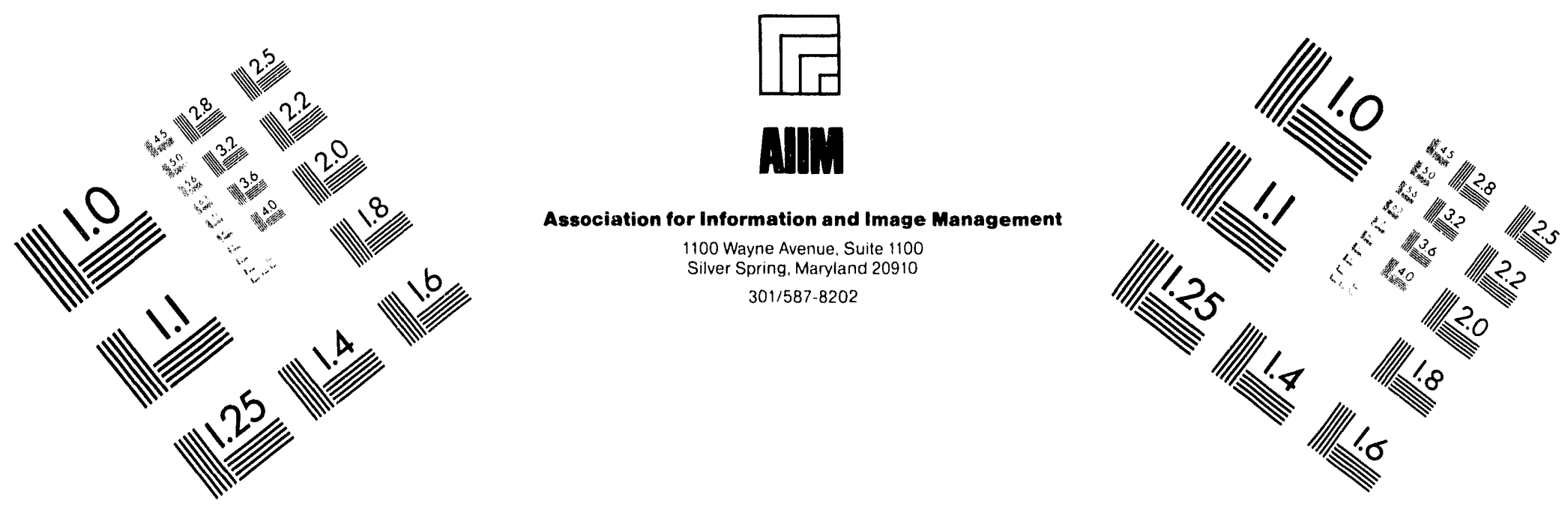

\title{
Centimeter
}

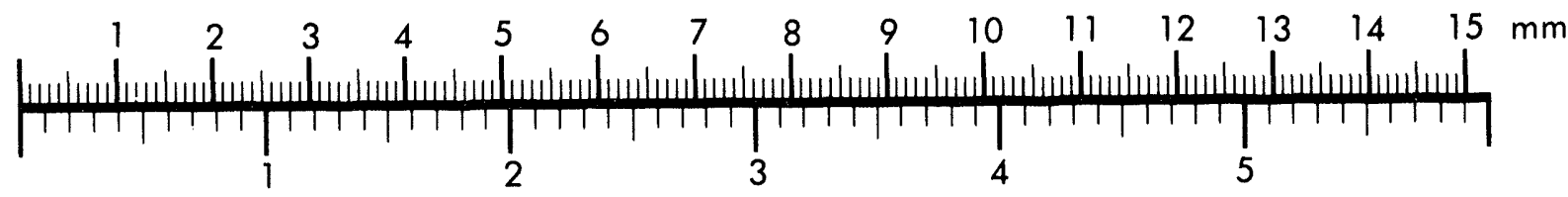
Inches
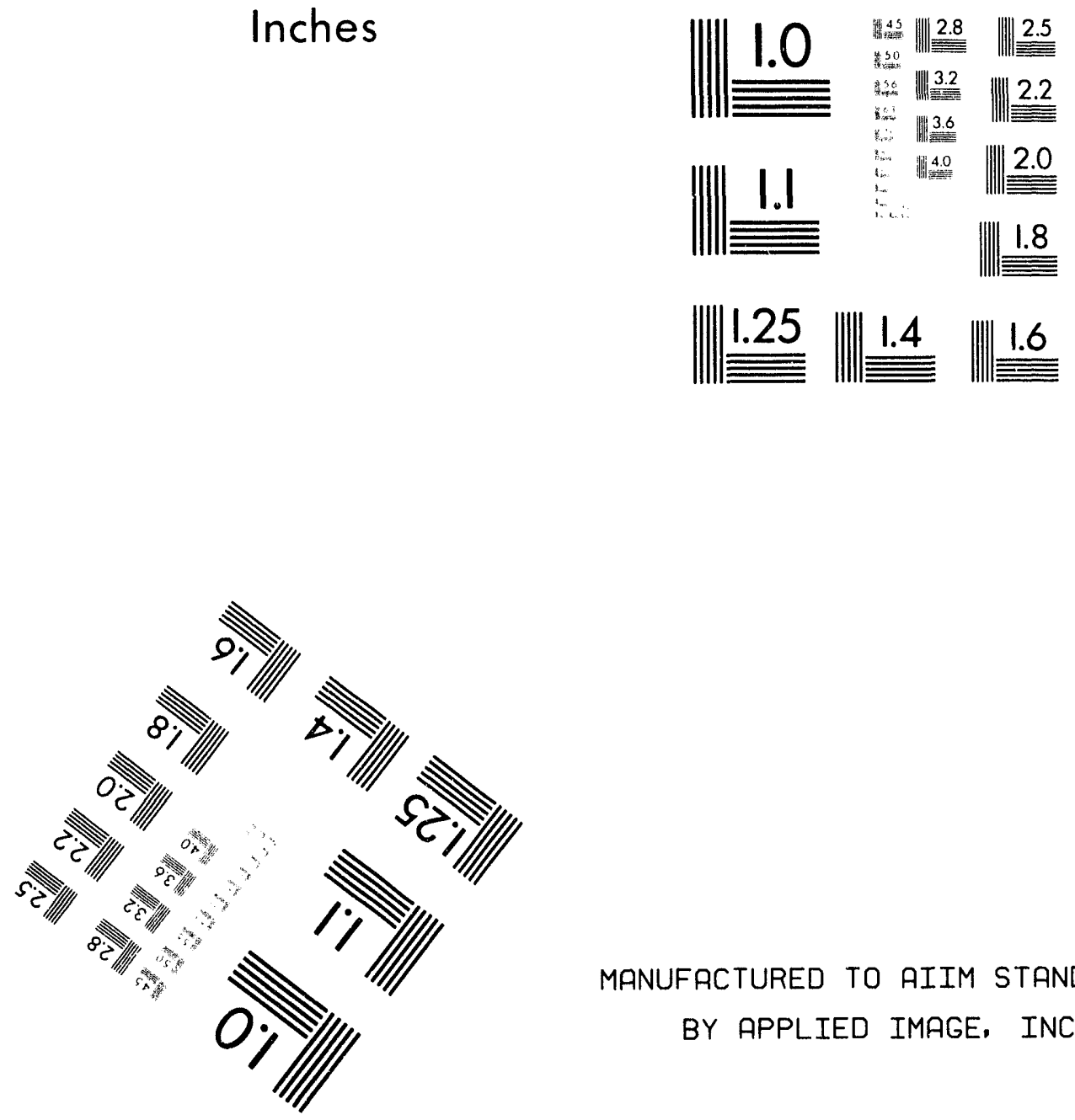

MANUFACTURED TO AIIM STANDARDS

BY APPLIED IMAGE, INC.

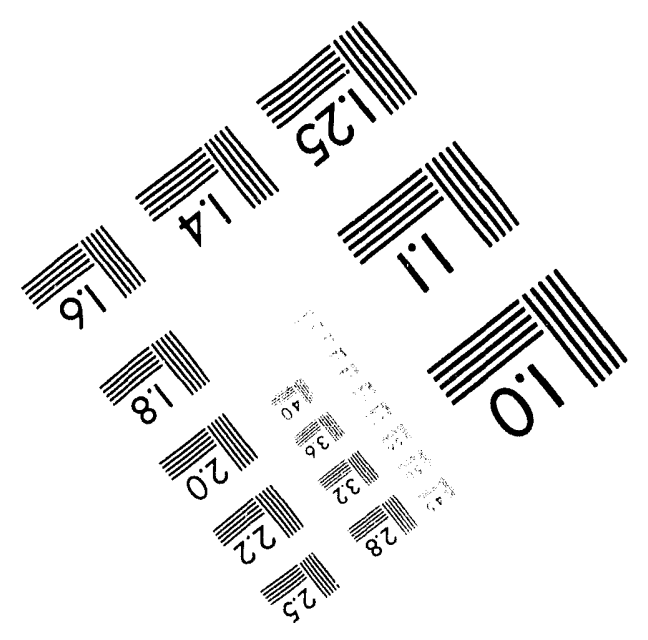



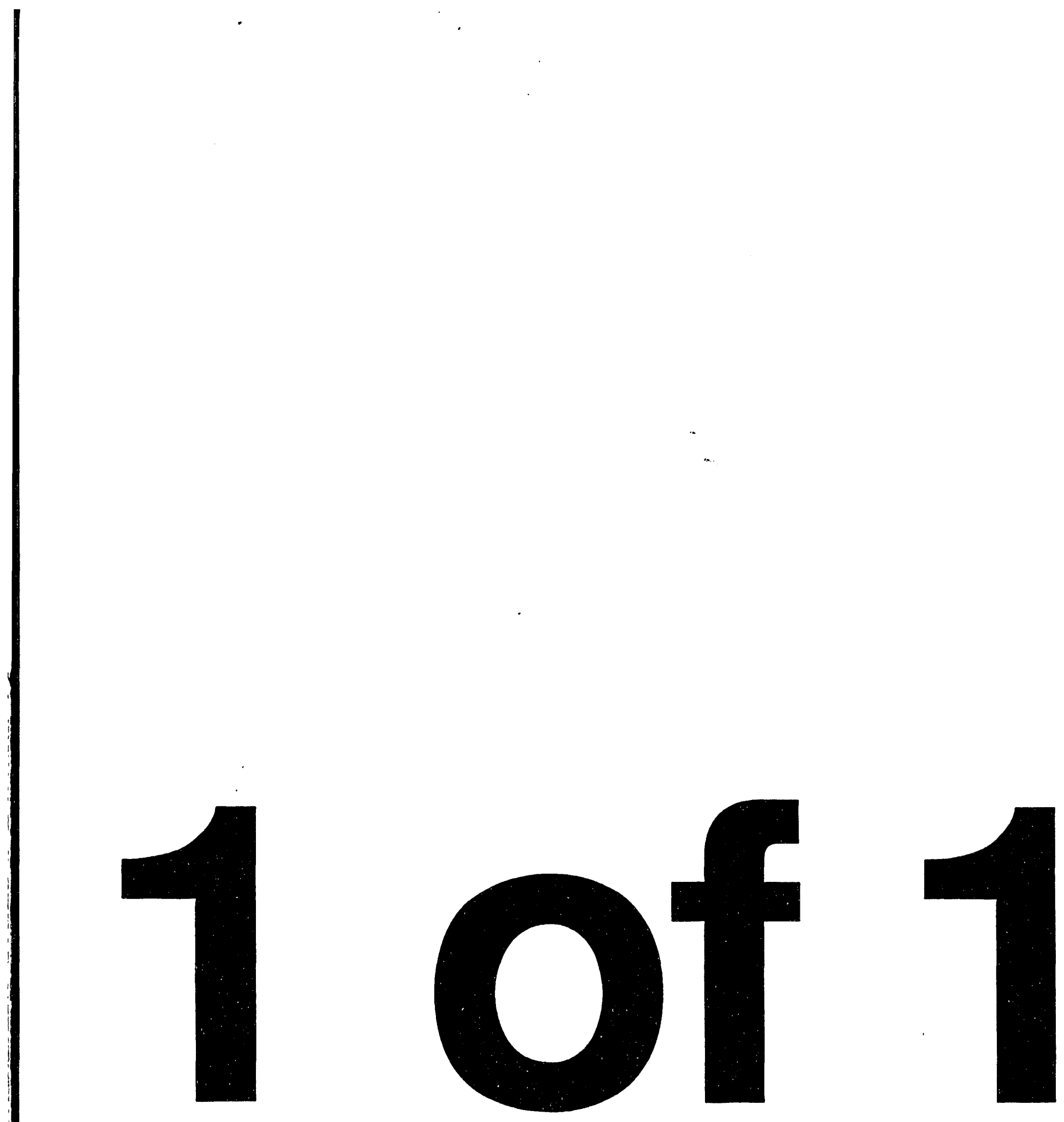


\title{
DISCLAIMER
}

This report was prepared as an account of work sponsored by an agency of the United States Government. Neither the United States Government nor any agency thereof, nor any of their employees, makes any warranty, express or implied, or assumes any legal liability or responsibility for the accuracy, completeness, or usefulness of any information, apparatus, product, or process disclosed, or represents that its use would not infringe privately owned rights. Reference herein to any specific commercial product, process, or service by trade name, trademark, manufacturer, or otherwise does not necessarily constitute or imply its endorsement, recommendation, or favoring by the United States Government or any agency thereof. The views and opinions of authors expressed herein do not necessarily state or reflect those of the United States Government or any agency thereof.

\section{PCR Detection of Retinoblastoma Gene Deletions in Radiation-induced Mouse Lung Adenocarcinomas}

Mark E. Churchill, M. Anne Gemmell, and Gayle E. Woloschak

\author{
Biological and Medical Research Division \\ Argonne National Laboratory \\ 9700 S. Cass Avenue \\ Argonne, IL 60439-4833
}

Running Title:

$R b$ Gene Deletions in Radiation-induced Tumors

Person to whom correspondence should be sent: Gayle Woloschak

Biological and Medical Research Division

Argonne National Laboratory

9700 South Cass Avenue

Argonne, IL 60439-4833

\section{MASTER}

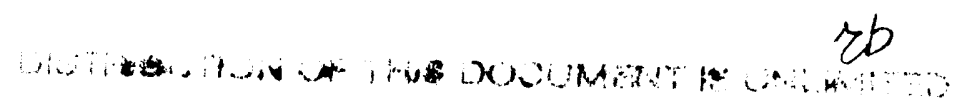




\section{ABSTRACT}

From 1971-1986, Argonne National Laboratory conducted a series of large-scale studies of tumor incidence in $40,000 \mathrm{BCF}_{1}$ mice irradiated with ${ }^{60} \mathrm{Co} \gamma$-rays or JANUS fissionspectrum neutrons; normal and tumor tissues from mice in these studies were preserved in paraffin blocks. A polymerase chain reaction (PCR) technique was developed to detect deletions in the mouse retinoblastoma $(m R b)$ gene in the paraffin-embedded tissues. Microtomed sections were used as the DNA source in PCR reaction mixtures. Six $m R b$ gene exon fragments were amplified in a 40-cycle, 3-temperature PCR protocol. Absence of any of these fragments (relative to control PCR products) on a Southern blot indicated a deletion of that portion of the $m R b$ gene. Tumors chosen for analysis were lung adenocarcinomas that were judged to be the cause of death in post-mortem analyses. Spontaneous tumors as well as those from irradiated mice (569 CGy of ${ }^{60} \mathrm{Co} \gamma$-rays or $60 \mathrm{CGy}$ of JANUS neutrons, doses been found to have approximately equal biological effectiveness in the $\mathrm{BCF}_{1}$ mouse) were analyzed for $m R b$ deletions. In all normal mouse tissues studies (18 total), all six $m R b$ exon fragments were present on Southern blots. Tumors in six neutron-irradiated mice also had no $m R b$ deletions. However, 1 of 6 tumors from $\gamma$-irradiated mice $(17 \%)$ and 6 of 18 spontaneous tumors from unirradiated mice (33\%) showed a deletion in one or both $m R b$ alleles. All deletions detected were in the $5^{\prime}$ region of the $m R b$ gene.

The authors thank Dr. Bruce Carnes and Ms. Betty Jean Wright for their expert assistance in selecting tumors for study, Ms. Kay Bexson for excellent secretarial assistance, and Drs. Carcl Giometti, Radoje Drmanac, Lydia Ling-Indeck, and Frank Collart for reviewing this manuscript. Work supported by the U.S. Department of Energy, Office of Health and Environmental Research, under Contract No. W-31-109-ENG-38. 


\section{INTRODUCTION}

Ionizing radiation is known to be both mutagenic and carcinogenic (Upton 1984; Shigematsu and Kagan 1986). Many studies have focused in vitro on radiation-induced transformation in cultured cells (Borek 1979; Elkind and Han 1979; Kennedy et al. 1984) and on in vivo malignant tumor formation in whole animals (United Nations Scientific Committee on Effects of Atomic Radiation 1977,1982; Grahn et al. 1990,1992). It is widely accepted that radiation-induced cell killing and mutations are the result of DNA damage, including DNA strand breaks, base modifications, insertions and deletions (Yunis 1983; Hutchinson 1985). However, little is known about the specific molecular mechanisms by which ionizing radiation induces cellular transformation. We report the development of a PCR technique which allows detection of large DNA deletions in paraffin-embedded lung adenocarcinomas from mice irradiated with ${ }^{60} \mathrm{Co} \gamma$-rays or JANUS fission-spectrum neutrons.

From 1971-1986, Argonne National Laboratory conducted a large-scale study of tumor incidence in approximately $40,000 \mathrm{BCF}_{1}$ mice irradiated with ${ }^{60} \mathrm{Co} \gamma$-rays or JANUS fission-spectrum neutrons (Grahn et al. 1990, 1992). Pathologic examinations of the mice were conducted to determine the effects of varying radiation doses and dose schedules on the formation of neoplasias classified as "lethal" or "contributing to death." The tumors and normal tissues were fixed in buffered formalin and preserved in paraffin blocks for later analyses. Although the quality of DNA in these paraffin-preserved tissues was generally not sufficient for ordinary Southern blot studies, specific sequences from the DNA can be amplified and detected using PCR technology (Goeltz et al. 1985; Impraim et al. 1987; Shibata et al. 1988). The preserved tissues from this $B C F_{1}$ mouse study thus have the potential to provide a wealth of information about the molecular genetics of radiation-induced tumor formation in mice. 
MATERIALS AND METHODS

cDNA clones. We thank the following individuls for generously providing cDNA clones: Dr. Dryja (Harvard Univ., Boston, MA) for Rb cDNA and Dr. David Baltimore (Rockefeller Univ., New York, NY) for Rag-1 cDNA.

Tissue Samples. During the Argonne mouse irradiation study, a database containing information on each mouse involved in the study was established. We selected paraffin blocks of mouse tissues for our study based on information from this database. Control mice and mice that had been irradiated with known doses of radiation were identified, and paraffin blocks containing normal lungs or lung adenocarcinomas from these mice were retrieved from the Argonne Tissue Repository for use in the study.

$\mathrm{BCF}_{1}$ mice $(\mathrm{C} 57 \mathrm{BL} / 6 \times \mathrm{BALB} / \mathrm{c})$ were bred in the Argonne animal facility. Mice entered the experiment at 16 weeks of age. Radiation facilities, dosimetry, and methods of exposure have been reported in detail by Grahn et al. (1972) and Williamson and Frigerio (1972). The lung tissues used in this study were derived from male mice irradiated with a single dose of either $569 \mathrm{CGy}$ of ${ }^{60} \mathrm{Co} \gamma$-rays or $60 \mathrm{cGy}$ of JANUS fission-spectrum neutrons (JANUS neutrons have a mean energy of $0.85 \mathrm{MeV}$ and a $\gamma$-ray contamination level of only $2.5 \%)$. Control mice were not irradiated. The $\gamma$-ray and neutron doses chosen have approximately equal biological effectiveness in the $B C F_{1}$ mouse (Grahn et al., 1990, 1992).

DNA Sample Preparation and PCR Protocol. Paraffin tissues were prepared for PCR by the method of Wright and Manos (1990). Primers (20-mers) for amplification of six segments of the $m R b$ gene were designed according to the cDNA sequence (from $5^{\prime}$ to $3^{\prime}$ ) published in Bernards et al. (1989); see Table 1. Segments 1-5 are contained in the coding region, and segment 6 is contained in the $3^{\prime}$ untranslated region. Sequences of the primers $\left(5^{\prime}\right.$ to $\left.3^{\prime}\right)$ were: 
Sense 1: TGACACAACCCAGCAGTGCG; Anti 1: TTACCAGGTCATCTTCCATC;

Sense 2: TCGAGGTTCTCTGTAAAGAA; Anti 2: GGATCAGTCTGAAGTGTTTT;

Sense 3: GCAAACTCCTAAATGACAAC; Anti 3: TCTGCTATACGTAGCCATTA;

Sense 4: TTGAAATCTACCTCCCTTGC; Anti 4: TCTCATGAGCTCATACTCAT;

Sense 5: GGTAACATCTATATATCACC; Anti 5: TGATTCACCAATTGAGACCA;

Sense 6: ACAGATTTCATACCTCAGAC; Anti 6: CAACCTTGGAGTATTATCAA. Primers (20-mers) for amplification of the Rag-1 gene standard were based on the cDNA sequence published by Schatz et al. 1989. The sense primer (1063-1082) was 5'-

CTATTGTCCCTCTTGCCGAT- ${ }^{\prime}$ and the antisense primer (1571-1590) was $5^{\prime}$ GGTTGAAAAATCTGCCTCCC-3', giving a 528 bp fragment.

PCR reaction mixtures $(50 \mu \mathrm{L})$ were run in a Perkin Elmer Cetus DNA Thermal Cycler and contained: $10 \mathrm{mM}$ Tris $\mathrm{HCl}, \mathrm{pH} 8.3 ; 50 \mathrm{mM} \mathrm{KCl} ; 1.5 \mathrm{mM} \mathrm{MgCl}_{2} ; 200 \mu \mathrm{M}$ each dATP, $\mathrm{dCTP}, \mathrm{dGTP}, \mathrm{dTTP} ; 0.3 \mu \mathrm{M}$ each primer; $5.0 \mu \mathrm{L}$ tissue digest; and a $45 \mu \mathrm{L}$ mineral oil overlay. This reaction mixture was held at $94^{\circ} \mathrm{C}$ for $5 \mathrm{~min}, 1.25$ units of Taq polymerase was added. (hot start), and the following protocol was used for amplification: $1 \mathrm{~min}$ at $94^{\circ} \mathrm{C} / 1$ $\min$ at $42{ }^{\circ} \mathrm{C} / 2 \mathrm{~min}$ at $65^{\circ} \mathrm{C}: 40$ cycles; $7 \mathrm{~min}$ at $65^{\circ} \mathrm{C}: 1$ cycle. Amplified reaction mixtures were stored at $-20^{\circ} \mathrm{C}$ until being used for electrophoresis. Amplifications of the $m R b$ and Rag-1 genes were done under the same conditions.

Southern Blot Procedure. PCR reaction mixtures $(18 \mu \mathrm{L})$ of the $m R b$ gene were run on a 3.2\% NuSieve 3:1 Agarose (FMC) gel at $90 \mathrm{~mA}$ for $4 \mathrm{~h}$. The gel was denatured two times for $30 \mathrm{~min}$ in $0.6 \mathrm{M} \mathrm{NaOH} / 1.5 \mathrm{M} \mathrm{NaCl}$ and neutralized two times for $30 \mathrm{~min}$ in $1.5 \mathrm{M}$ Tris $\mathrm{HCl} / 1.5 \mathrm{M} \mathrm{NaCl}, \mathrm{pH}$ 8.0. The DNA was transferred to an MSI neutral nylon membrane with 10X SSC transfer buffer. The membrane was rinsed, dried, and UV-crosslinked. Membranes were hybridized to ${ }^{32} \mathrm{P}$ random hexanucleotide-labeled $m R b$-containing plasmid 
in BIOS Speed-Hyb solution at $53^{\circ} \mathrm{C}$. Membranes were washed four times in $2 \mathrm{XSSC}, 0.5 \%$ SDS at $53^{\circ} \mathrm{C}$, dried, and autoradiographed. PCR reaction mixtures of the Rag-1 gene were run similarly except for the following: $1.5 \% \mathrm{ME}$ agarose gel (FMC) was run at $80 \mathrm{~V}$ for $4 \mathrm{~h}$; the gel was denatured and neutralized only once each; the Rag-1 plasmid was used for probing; and washing was in $0.5 \mathrm{XSC}, 0.5 \%$ SDS $3 X$ at $53^{\circ} \mathrm{C}$.

Method of Quantitating $m \boldsymbol{R} b$ Deletions. The basic idea in quantitating deletions was to amplify the six $m R b$ PCR segments from control and tumor tissues and quantitate the intensity of autoradiograph bands by microdensitometry. Because it was impossible to eliminate all normal tissue from the tumor samples, bands from a tumor tissue with a deletion are lighter than bands from control tissues, but may not be completely absent. Furthermore, the intensity of bands will be different on different blots due to differences in amount of probe used, efficiency of crosslinking, etc. Thus, PCR fragment \#4 was amplified using $m R b$ cDNA plasmid. When a Southern blot containing PCR amplifications of tumor or normal paraffin tissues was run, a known amount of the standard band \#4 was included on the gel. The intensity of each band on the gel was compared to the intensity of this standard band, giving a mathematical ratio that allows standardization of band intensities from gel to gel and sample to sample. We designate this ratio R1: $\mathrm{R} 1=$ Intensity of paraffin $m R b$ band/intensity of standard $m R b$ band. Because the efficiency of amplification and the amount of tissue used varied from sample to sample, a standard gene that was not deleted in tumors (Rag-1) was amplified, and the intensity of this band was used to correct for amplification efficiency and amount of tissue used. The intensity of the band produced (528 bp) was compared to the intensity of a standard Rag-1 band prepared by PCR of a Rag-1 cDNA plasmid. The ratio $R 2$ was designated: $R 2=$ intensity of paraffin $R a g-1$ band/intensity of standard Rag-1 band. In order to evaluate whether one $m R b$ band was less abundant than another, each band was assigned a ratio $R: R=R 1 / R 2$. We have determined 
that bands from control tissues had $\mathrm{R}$ values that were greater than 0.2 , often as large as 5.0 , while bands from tumor tissues with $m R b$ deletions had $\mathrm{R}$ values that were small (usually 0 to 0.1 ).

\section{RESULTS}

Table 2 presents results of $m R b$ amplifications. No normal lung tissues of the 18 examined showed deletion of the six $m R b$ fragments tested. This was true of normal lungs from both unirradiated and irradiated animals. The $\mathrm{R}$ values for all bands amplified from normal lung tissues were 0.2 or greater, indicating the presence of the band. For tumor tissues, only bands with $R$ values less than 0.2 (usually less than 0.1 ) were considered to be deleted. One paraffin block containing normal lung tissue consistently failed to amplify either $m R b$ or $R a g-1$ fragments because of extensive necrosis of the tissue before preservation. This tissue, which was treated the same as all others, served as a negative PCR control.

Normal lung tissue from unirradiated mice (12 samples), $\gamma$-irradiated mice (6 samples), and neutron-irradiated mice (6 samples) showed the presence of all $m R b$ bands in all blots $(R>0.2)$. All adenocarcinomas studied were determined by post-mortem analysis to be the cause of death of the animals. In 12 of 18 adenocarcinomas that developed in unirradiated mice, no $m R b$ deletions were detected. In 6 of $18(33 \%)$ spontaneous adenocarcinomas, $m R b$ deletions were detected. Four of the tumors had a deletion of fragments 1 and 2, while two of the tumors had a deletion of fragments 1, 2, and 3. In 5 of 6 adenocarcinomas from $\gamma$-irradiated animals, no $m R b$ deletions were detected. One of the tumors had a deletion of fragments 2 and 3 . In 6 adenocarcinomas that developed in neutron-irradiated mice, none showed an $m R b$ deletion. These data are summarized in Table 2.

\section{DISCUSSION}

It was not practical to amplify the entire $m R b$ gene for two reasons: (1) a large 
number of fragments sized 250 bp or smaller would be necessary to amplify a 4.7-kb gene and (2) the intron structure for the entire $m R b$ gene is not known. The technique of detecting $R b$ deletions used here has several inherent limitations. First, if the fragment being amplified is present in one allele but deleted in the other, a band will still appear on the Southern blot. Since both alleles of the $R b$ gene are usually mutated in tumors (Dunn et al. 1989; Stanbridge 1990) this limitation is reasonable. Second, deletions in the $m R b$ gene that fall between PCR fragments in the gene sequence will not be detected. Because this study focused exclusively on $m R b$ coding regions, deletions in introns or in non-amplified coding regions of the $m R b$ gene would be missed using this approach. However, large deletions, sometimes of the entire gene, are often found in retinoblastomas (Dunn et al. 1989), so it is reasonable to expect that tumors will be found having large $m R b$ deletions that can be detected by our technique. Third, point mutations or small deletions and insertions will not be detected. A point mutation in the primer sequence might prevent primer binding during the PCR annealing step. However, our annealing temperature of $42{ }^{\circ} \mathrm{C}$ (necessary because of the low GC content of the $m R b$ primers) is not sufficiently stringent to detect point mutations in the primer sequence. Future experiments aimed at increasing the resolution of the technique are being planned.

All the $m R b$ deletions found in $\mathrm{BCF}_{1}$ lung adenocarcinomas were located at the $5^{\prime}$ end of the gene, involving fragments 1,2 , and 3, thus generating alterations in the $\mathrm{N}$-terminus of the $\mathrm{Rb}$ protein. This result is in contrast to results obtained in human retinoblastomas, in which deletions have been found throughout the entire gene (Dunn et al. 1989; Kloss et al. 1991). The functional significance of $5^{\prime}$ deletions in the mouse adenocarcinomas is not known. The $\mathrm{Rb}$ protein is a DNA-binding protein (Stanbridge 1990), and association of $\mathrm{Rb}$ protein with viral transforming proteins such as SV40 large-T antigen or adenovirus E1A protein, inactivates it (Kaelin et al. 1990). The $m R b$ deletions observed in the tumors 
examined in this report could cause a total absence of $m R b$ protein in cells or to a deletion of a portion of the protein required for a critical cellular function. A region of the amino acid sequence in human $\mathrm{Rb}$ protein from residues 379 to 792 has been identified as being required for binding of $\mathrm{Rb}$ protein to SV40 large-T antigen and E1A protein (Kaelin et al. 1990). However, the deletion of $m R b$ gene fragments 1 and 2 in mice is not in this region (they would cover amino acid residues 169 to 347 ). The presence of so many deletions at the $\mathrm{N}$ terminal end of the $\mathrm{Rb}$ protein is highly suggestive that the presence of this region is essential for the normal function of $\mathrm{Rb}$ protein in mice.

Contrary to our expectation in designing this study, all but one $m R b$ deletion was found in spontaneous tumors rather than in tumors from irradiated mice. It is obvious that deletions in the $m R b$ gene occur commonly in the absence of irradiation. Our data suggest that $\boldsymbol{\gamma}$ - or neutron-irradiation does not cause an increased frequency of $m R b$ deletions. The observed increase in frequency of lung adenocarcinomas upon $\gamma$ - or neutron-irradiation of mice (Grahn et al. 1990, 1992) is apparently the result of a mechanism other than $m R b$ deletion. Experiments are underway to examine these tissues for lesions in other dominant and suppressor oncogenes. 


\section{REFERENCES}

Bernards, R., Schackleford, G. M., Gerber, M. R., Horowitz, J. M., Friend, S. H., Schartl, M., Bogenmann, E., Rapaport, J. M., McGee, T., Dryja, T. P., and Weinberg, R. A.

Structure and expression of the murine retinoblastoma gene and characterization of its encoded protein. Proc. Natl. Acad. Sci. USA, 86: 6474-6478, 1989.

Borek, C. Malignant transformation in vitro: criteria, biological markers, and application to environmental screening of carcinogens. Radiat. Res., 70: 209-232, 1979.

Dunn, J. M., Zhu, X., Gallie, B. L., and Phillips, R. A. Characterization of mutations in the RB1 gene. In: W. Cavanee, N. Hastie, and E. Stanbridge (eds.), Current Communications in Molecular Biology, Recessive Oncogenes and Tumor Suppression, New York: Cold Spring Harbor Laboratory Press, 93-100, 1989.

Elkind, M. M., and Han, A. Neoplastic transformation and dose fractionation: does repair of damage play a role? Radiat. Res., 79: 233-240, 1979.

Goeltz, S. E., Hamilton, S. R., and Vogelstein, B. Purification of DNA from formaldehyde fixed and paraffin embedded human tissue. Biochem. Biophys. Res. Comm., 130: 118$126,1985$.

Grahn, C., Thomson, J. F., and Carnes, B. Relative biological effectiveness (RBE) of fission neutrons and gamma rays at occupational exposure levels, Volume III: Studies on the gross microscopic pathology observed at death of mice exposed to 60 equal onceweekly doses of fission neutrons and gamma rays. U. S. Nuclear Regulatory Commission publication NUREG/CR-4704 (ANL-86-33), Vol. 3, 1990.

Grahı, D., Lombard, L. S., and Carnes, B. A. The comparative tumorigenic effects of fission neutrons and cobalt-60 $\gamma$ rays in the B6CF mouse. Radiat. Res. 129: 19-36, 1992.

Grahn, D., Ainsworth, E. J., Williamson, F. S., and Fry, R. J. M. A program to study fission neutron-induced chronic injury in cells, tissues and animal populations, utilizing the 
JANUS reactor of the Argonne National Laboratory. In: Radiobiological Applications of Neutron Irradiation, Vienna: International Atomic Energy Agency, 211-228, 1972.

Hutchinson, F. Chemical changes induced in DNA by ionizing radiation. Progr. Nucleic Acid Res. Mol. Biol., 32: 115-125, 1985.

Impraim, C. C., Saiki, R. K., Erlich, H. A., and Teplitz, R. L. Analysis of DNA extracted from formalin-fixed, paraffin-embedded tissues by enzymatic amplification and hybridization with sequence-specific oligonucleotides. Biochem. Biophys. Res. Comm., 142: 710-716, 1987.

Kaelin, W. G., Ewen, M. E., and Livingston, D. M. Definition of the minimal Simian Virus 40 large $\mathrm{T}$ antigen- and adenovirus E1A-binding domain in the retinoblastoma gene product. Mol. Cell. Biol., 10: 3761-3769, 1990.

Kennedy, A. R., Cairns, J., and Little, J. B. Timing of the steps in transformation of C3H 10T1/2 cells by $x$-irradiation. Nature, 307: 85-86, 1984.

Kloss, K., Wahrisch, P., Greger, V., Messmer, E., Fritze, H., Hopping, W., Passarge, E., and Horsthemke, B. Characterization of deletions at the retinoblastoma locus in patients with bilateral retinoblastoma. Amer. J. Med. Genet., 39: 196-200, 1991.

Schatz, D. G., Oettinger, M. A., and Baltimore, D. The V(D)J recombination activating gene, Rag-1. Cell, 59: 1035-1048, 1989.

Shibata, D. K., Arnheim, N., and Martin, W. J. Detection of human papilloma virus in paraffin-embedded tissue using the polymerase chain reaction. J. Exp. Med., 167: 225-230, 1988.

Shigematsu, I., and Kagan, A. Cancer in atomic bomb survivors. GANN Monograph on Cancer Research, 32, Tokyo: Japan Scientific Societies Press and New York: Plenum Press, 1986.

Stanbridge, E. J. Human tumor suppressor genes. Ann. Rev. Genet., 24: 615-657, 1990. 
United Nations Scientific Committee on the Effects of Atomic Radiation. Ionizing radiation: sources and biological effects. Report to the General Assembly, with annexes. New York: United Nations, 1982.

United Nations Scientific Committee on the Effects of Atomic Radiation. Sources and effects of ionizing radiation. Report to the General Assembly, with annexes. New York: United Nations, 1977.

Upton, A. C. Biological aspects of radiation carcinogenesis. In: J. D. Boice and J. F. Fraumeni (eds.), Radiation Carcinogenesis: Epidemiology and Biological Significance, New York: Raven Press, p. 9, 1984.

Williamson, F. S., and Frigerio, N. A. Field mapping and depth dosimetry in the JANUS high flux irradiation room - a fast neutron facility for biological research. In: G. Burger, M. Schraube, and H. G. Ebert (eds.), Proceedings of the First Symposium on Neutron Dosimetry in Biology and Medicine, Commission of the European Communities, Luxembourg, pp. 743-755, 1972.

Wright, D. K., and Manos, M. M. Sample preparation from paraffin-embedded tissues. In: M. A. Innis, D. H. Gelfand, J. J. Sninsky, and T. J. White (eds.), PCR Protocols: a Guide to Methods and Applications, San Diego: Academic Press, pp. 153-158, 1990.

Yunis, J. J. The chromosomal basis of human neoplasia. Science, 221: 227-236, 1983. 
Table 1. Amplified segments in $m R b$ gene

\begin{tabular}{cccc}
\hline Segment \# & Sense Primer & Antisense Primer & $\begin{array}{c}\text { Length of Segment } \\
\text { Amplified }\end{array}$ \\
\cline { 3 - 4 } 1 & $601-620$ & $701-720$ & $120 \mathrm{bp}$ \\
2 & $901-920$ & $1101-1120$ & $220 \mathrm{bp}$ \\
3 & $1501-1520$ & $1561-1580$ & $80 \mathrm{bp}$ \\
4 & $2001-2020$ & $2146-2165$ & $165 \mathrm{bp}$ \\
5 & $2481-2500$ & $2572-2591$ & $111 \mathrm{bp}$ \\
6 & $3501-3520$ & $3575-3594$ & $94 \mathrm{bp}$ \\
\hline
\end{tabular}


Table 2. $m R b$ deletions detected in $\mathrm{BCF}^{1}$ mouse lung adenocarcinomas

\begin{tabular}{|c|c|c|}
\hline Irradiation condition & $\begin{array}{c}\text { Number of } \\
\text { adenocarcinomas tested }^{2}\end{array}$ & $\begin{array}{c}\text { Number of } m R b \\
\text { deletions found (\%) }\end{array}$ \\
\hline Unirradiated & 18 & $6(33 \%)$ \\
\hline$\gamma$-irradiated $^{b}$ & 6 & $1(17 \%)$ \\
\hline Neutron-irradiated $^{c}$ & 6 & $0(0 \%)$ \\
\hline
\end{tabular}

a'Deletions were not found in 12 normal lung tissues from irradiated and 6 normal lung tissues from untreated mice.

${ }^{2}$ Animals received a single $569-\mathrm{cGY}$ dose of ${ }^{60} \mathrm{Co} \gamma$-rays in $20 \mathrm{~min}$.

${ }^{3}$ Animals received a single $60-\mathrm{cGy}$ dose of JANUS fission-spectrum neutrons in $20 \mathrm{~min}$. 


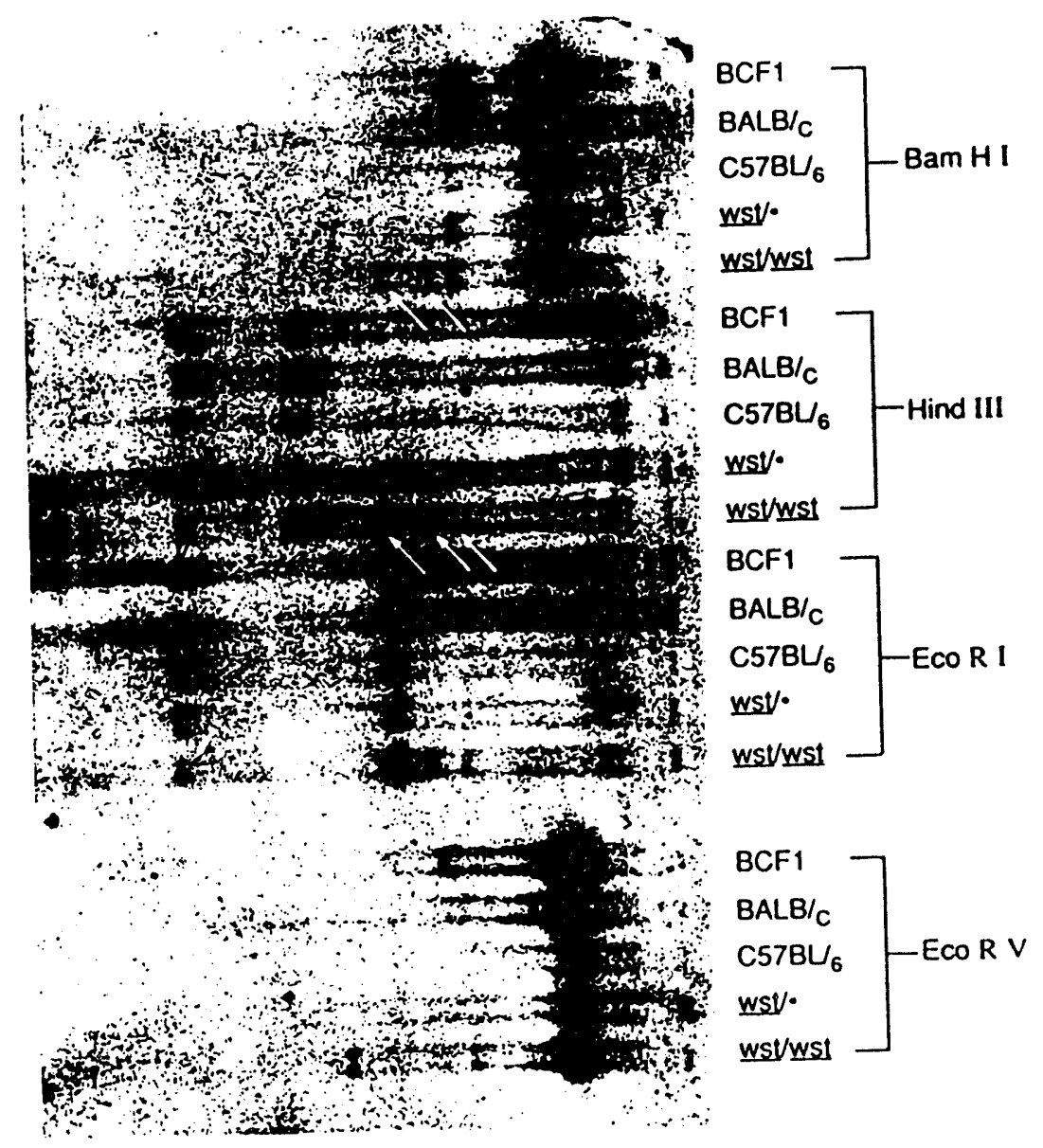



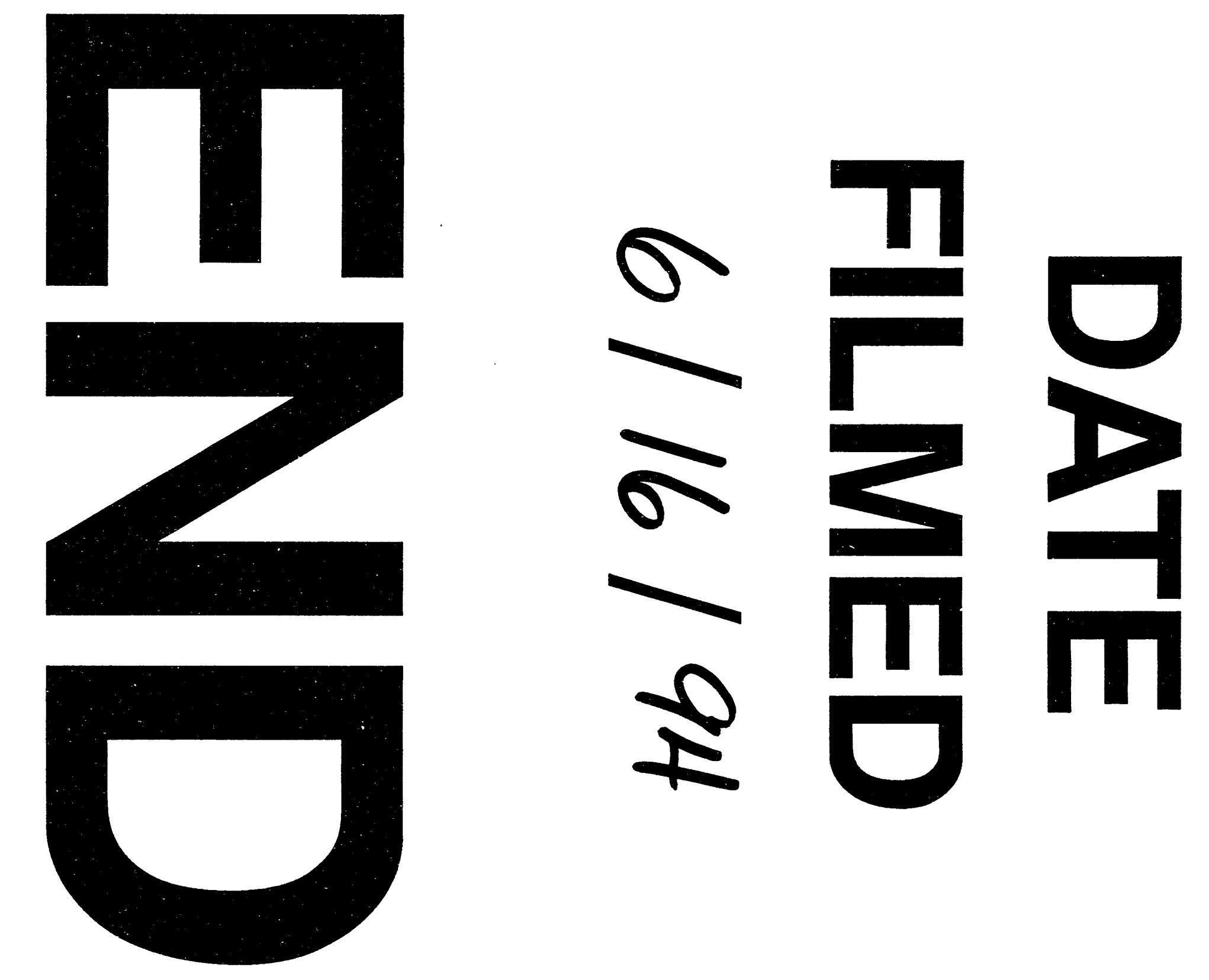

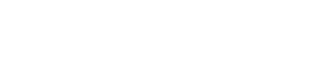

更

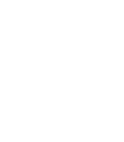

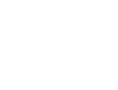
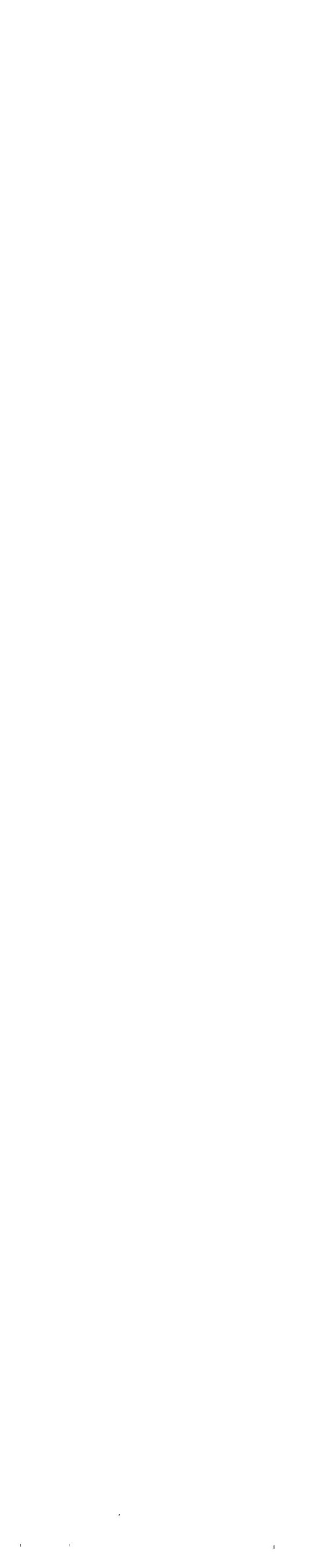

. 